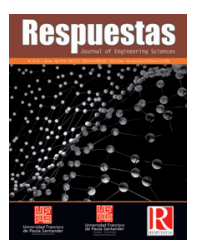

Original Article
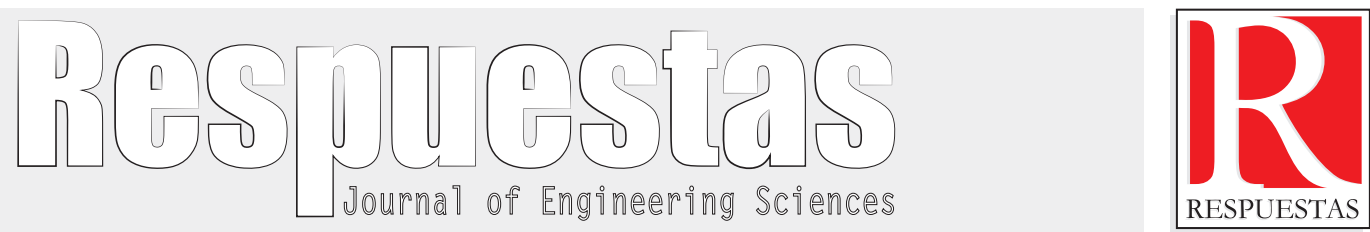

\title{
Behavior of an asphalt mixture MDC-19 under the cycles of ambient temperature in the city of Tunja, Colombia
}

Comportamiento de una mezcla asfáltica MDC-19 bajo los ciclos de temperatura ambiente en la ciudad de Tunja, Colombia

Carol Rosabeth Sanabria-Sanabria ${ }^{1}$, Carlos Hernando Higuera-Sandoval ${ }^{*}$

${ }^{1}$ Magister en Ingeniería con énfasis en Infraestructura vial, carol.sanabria@uptc.edu.co, ORCID: 0000-0001-6681-8401, Universidad Pedagógica y

Tecnológica de Colombia, Tunja, Colombia.

2*Magíster en Ingeniería de Vias Terrestres, carlos.higuera@uptc.edu.co, ORCID: 0000-0003-1333-2517, Universidad Pedagógica y Tecnológica de Colombia, Tunja, Colombia.

How to cite: C. Sanabria-Sanabria y C. Higuera-Sandoval, "Behavior of an asphalt mixture MDC-19 under the cycles of ambient temperature in the city of Tunja, Colombia". Respuestas, vol. 24, no. 1, pp. 54-63, 2019.

Received on May 25, 2018; Approved on September 30, 2018

\begin{tabular}{|c|c|}
\hline & ABSTRACT \\
\hline Keywords: & The weather factor plays an important role in the behavior and performance of asphalt mixtures as a surface \\
\hline Cycles of ambient & layer in a flexible pavement structure, not just from the moisture, but also from the environmental temperature. \\
\hline temperature & \\
\hline Density & $\begin{array}{l}\text { Which usually occur when the highest temperatures are reached during the daytime, and the lowest } \\
\text { temperatures annear at night and early morning time Firstly this research is based on the definition of the }\end{array}$ \\
\hline Stability & environmental temperature cycles that occur daily in Tunja City, from the analysis of the temperature series. \\
\hline Marshall Flow & Subsequently, the analysis was done through laboratory tests on an asphalt mix MDC-19 INVIAS type, made \\
\hline $\begin{array}{l}\text { Bulk specific } \\
\text { gravity }\end{array}$ & $\begin{array}{l}\text { and compacted in the laboratory, to determine the influence of the cycles of environmental temperature on } \\
\text { its density stability and flow properties during } 120 \text { dailv and continuous temnerature cycles, which consist }\end{array}$ \\
\hline MDC-19 & $\begin{array}{l}\text { its density, stability and flow properties, during } 120 \text { dally and continuous temperature cycles, which consist } \\
\text { of } 12 \text { hours of maximum temperature and } 12 \text { hours of minimum temperature to simulate the environmental }\end{array}$ \\
\hline Asphalt mix & $\begin{array}{l}\text { conditions. As a result of this investigation, the presentation density is presented, presenting a tendency to } \\
\text { increase the measurement that increases the temperature cycles and then a decrease in the briquettes of the } \\
\text { mixture that have sometimes been until the last cycles. Variations in the resistance to deformation of the } \\
\text { analysis mixture were obtained as the ambient temperature cycles were sometimes made, which concludes } \\
\text { that the ambient temperature cycles have an influence on the behavior of the asphalt mixture. }\end{array}$ \\
\hline
\end{tabular}

\section{RESUMEN}

Palabras clave: El factor clima juega un papel importante en el comportamiento y desempeño de las mezclas asfálticas como Ciclos de superficie de rodadura en una estructura de pavimento flexible, no solamente desde el punto de vista de la temperatura humedad sino también desde la temperatura ambiental. Las carpetas asfálticas de los pavimentos flexibles en ambiental Densidad Estabilidad y flujo

Marshall

Gravedad específica bulk MDC-19 la ciudad de Tunja se encuentran expuestas diariamente a variaciones de temperatura ambiental, las cuales ocurren generalmente cuando se alcanzan las máximas temperaturas en el día y las mínimas temperaturas durante la noche y madrugada. Esta investigación se fundamentó, en primer lugar, en la definición de los ciclos de temperatura ambiental que se presentan diariamente en la ciudad de Tunja a partir del análisis de la serie de temperaturas. Posteriormente, se llevó a cabo el análisis mediante ensayos de laboratorio a una mezcla asfáltica MDC-19 tipo INVIAS fabricada y compactada en laboratorio, con el fin de determinar la influencia que tienen los ciclos de variación de temperatura ambiental sobre las propiedades de densidad, estabilidad y flujo, durante 120 ciclos de temperatura diarios y continuos, los cuales consisten en 12 horas Mezcla asfáltica de temperatura máxima y 12 horas de temperatura mínima para simular las condiciones ambientales. Como resultado de esta investigación, se obtuvo que la densidad presenta inicialmente una tendencia al incremento a medida que aumentan los ciclos de temperatura y luego un descenso en las briquetas de la mezcla que han sido sometidas hasta los últimos ciclos. Se obtuvieron variaciones en la resistencia a la deformación de la mezcla de análisis a medida que se sometió a los ciclos de temperatura ambiental, con lo cual se concluye que los ciclos de la temperatura ambiental tienen influencia en el comportamiento de la mezcla asfáltica.

*Corresponding author.

E-mail address: carlos.higuera@uptc.edu.co (Carlos Hernando Higuera Sandoval)

(c) $(1) \Theta$ Peer review is the responsibility of the Universidad Francisco de Paula Santander.

(c) $\underbrace{}_{\mathrm{EY}}$ This is an article under the license CC BY-ND (http://creativecommons.org/licenses/by-nc-nd/4.0/). 


\section{Introduction}

Generally, flexible pavements are directly exposed to climatic changes [1] and must provide a stable, durable and uniform surface [2]. One of the factors that condition the behavior of asphalt mixtures is the ambient temperature [1], since they can be subject to temperature variations depending on local conditions. The above is applicable for pavements in Tunja, since the predominant climate is cold and in some seasons environmental temperatures can be reached from $-0.6^{\circ} \mathrm{C}$ to $25.4^{\circ} \mathrm{C}$ [3] - [4].

The surface layers of a pavement structure are usually constructed in bituminous materials such as hot dense asphalt mixtures [5] and being made up of materials of different nature, they vary in behavior and, therefore, the ambient temperature is considered one of the most conditioning external agents. Temperature plays a decisive role in asphalt cement as it has visco-elastic properties at a certain temperature; It behaves like an elastic solid under the action of low temperatures and tends to act as a viscous liquid at high temperatures [6].

Globally, the effect that cycles of ambient temperature variation have on asphalt mixtures (freezing and defrosting cycles) has been recognized as a factor that gives rise to problems to the extent that temperature exposure conditions fluctuate [7]. In order for these cycles to occur, extreme temperatures do not necessarily have to be reached in asphalt mixtures, in fact, this effect occurs more when temperatures are close to the freezing point, since this allows the cycles to fluctuate more from relatively low temperatures to temperatures greater.
The above was verified in the study carried out by Kestler [8], finding a relationship between fatigue damage and the duration of the winter seasons, that is to say that greater damages of this type occur in the mixtures when the winter periods are more Short and warmer temperatures [8].

Although the temperature variations in Tunja are not as drastic and the temperature periods differ, it was sought to identify the effect produced by the changes in ambient temperature on properties of the asphalt mixture. This document presents the final results of the research project "Behavior of an asphalt mixture MDC-19 under the cycles of temperature variation in the city of Tunja"; linked to the Road Infrastructure Research and Development Group GRINFRAVIAL.

\section{Materials and methods}

The hot dense asphalt mixture selected in this investigation is type MDC-19 INVIAS. The asphalt was supplied by Pavimentos Colombia S.A.S. and those added by the CSS Constructores S.A asphalt plant.

\section{Asphalt Cement}

The type of mixture of this study is designed for a rolling layer and NT2 transit level, with an asphalt type CA 80-100 for an average annual temperature of $13.3^{\circ} \mathrm{C}$ [3] - [4]. The characterization of asphalt cement was carried out in accordance with the provisions of INVIAS [9] and whose results are presented in Table I.

Table I. Characterization of the Asphalt cement CA 80-100 for MDC-19

\begin{tabular}{|c|c|c|c|c|c|}
\hline \multirow[t]{2}{*}{ CHARACTERISTIC } & \multirow{2}{*}{$\begin{array}{c}\text { STANDARD } \\
\text { OF } \\
\text { TEST }\end{array}$} & \multicolumn{2}{|c|}{\begin{tabular}{|c|} 
SPECIFICATION \\
INVIAS CA $80-$ \\
100
\end{tabular}} & \multirow[t]{2}{*}{ RESULT } & \multirow[t]{2}{*}{ CHECK } \\
\hline & & MÍN. & MÁX. & & \\
\hline \multicolumn{6}{|l|}{ ORIGINAL ASPHALT } \\
\hline Penetration $\left(25^{\circ} \mathrm{C}, 100 \mathrm{~g}, 5 \mathrm{~s}\right)$ & E-706 & 80 & 100 & 83 & Complies \\
\hline Softening point $\left({ }^{\circ} \mathrm{C}\right)$ & E-712 & 45 & 52 & 47.5 & Complies \\
\hline Penetration rate & E-724 & -1.2 & 0.6 & -0.6 & Complies \\
\hline Absolute viscosity $\left(60^{\circ} \mathrm{C}\right), \mathrm{P}$ & E-716 o 717 & 1000 & - & 1677 & Complies \\
\hline Ductility $\left(25^{\circ} \mathrm{C}, 5 \mathrm{~cm} / \mathrm{min}\right), \mathrm{cm}$ & E-702 & 100 & - & $113+$ & Complies \\
\hline $\begin{array}{l}\text { Flash point using Cleveland open cup }\left(^{\circ}\right. \\
\text { C) }\end{array}$ & E-709 & 230 & - & 236 & Complies \\
\hline \multicolumn{6}{|c|}{$\begin{array}{c}\text { RESIDUAL ASPHALT, AFTER THE CONDITIONING TEST IN } \\
\text { FILM ROTARY SLIM, TEST STANDARD INV-E-720-13 }\end{array}$} \\
\hline Loss of mass due to heating (\%) & E-720 & - & 1 & $-0.517 \%$ & Complies \\
\hline $\begin{array}{l}\text { Penetration of the residue, in } \% \text { of the } \\
\text { penetration of the original asphalt }\end{array}$ & E-706 & 46 & - & 55.4 & Complies \\
\hline Increase in softening point $\left({ }^{\circ} \mathrm{C}\right)$ & E-712 & - & 9 & 8.0 & Complies \\
\hline $\begin{array}{l}\text { Aging index: viscosity ratio }\left(60^{\circ} \mathrm{C}\right) \text { of } \\
\text { residual asphalt and original asphalt }\end{array}$ & E-716 o 717 & - & 4 & 3.4 & Complies \\
\hline
\end{tabular}


Asphalt cement meets the specifications for the original conditions and after aging; It can be said that this is a material that is characterized by its high ductility. Tests were performed with the rotational viscometer, resulting in the rheological curve and temperature ranges for mixing and compaction shown in Figure 1.

\section{Added}

The characterization of the stone aggregates was performed and the results were verified under the INVIAS - 2013 specifications [10]. See Table II.
The bulk specific gravity of the aggregate was calculated for the granulometry specified above, taking into account the specific gravity obtained with the laboratory tests performed on the materials, by (1) [9].

$$
G_{S b}=\frac{100}{\frac{P_{1}}{G_{1}}+\frac{P_{2}}{G_{2}}+\frac{P_{3}}{G_{3}}+\frac{P_{4}}{G_{4}}}
$$

Where: $G_{s b}:$ Bulk specific gravity of the aggregate, $P_{1}, P_{2}, P_{3}, P_{4}$ : Individual percentages of the different aggregates, $G_{1}, G_{2}, G_{3}, G_{4}$ : Bulk specific gravity of the fractions.
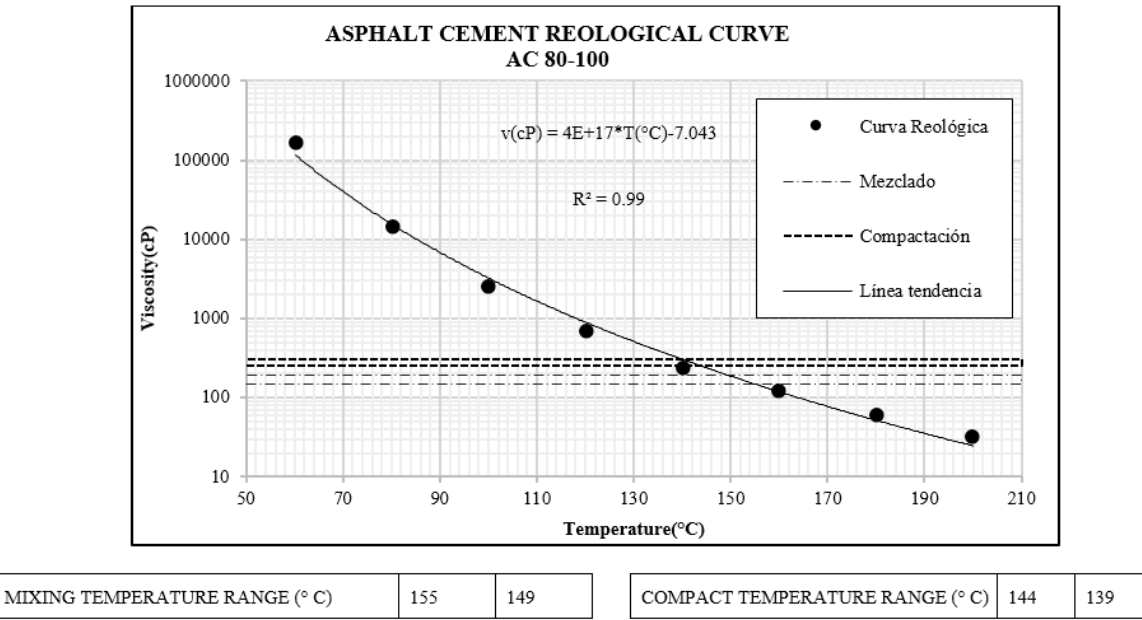

Figure 1. Asphalt cement rheological curve CA 80-100

Table II. Characterization of aggregates for MDC-19 Asphalt Mix

\begin{tabular}{|c|c|c|c|c|c|c|}
\hline \multirow{2}{*}{\multicolumn{2}{|c|}{ CHARACTERISTIC }} & \multirow[t]{2}{*}{$\begin{array}{c}\text { RULE } \\
\text { OF } \\
\text { TEST }\end{array}$} & \multicolumn{2}{|c|}{$\begin{array}{l}\text { SPECIFICATION } \\
\text { INVIAS-13 NT2. } \\
\text { Article } 450-13\end{array}$} & \multirow[t]{2}{*}{ RESULT } & \multirow[t]{2}{*}{ CHECK } \\
\hline & & & MÍN. & MÁX. & & \\
\hline \multicolumn{7}{|l|}{ GROSS ADDED HARDNESS } \\
\hline \multicolumn{2}{|c|}{$\begin{array}{l}\text { Wear on the Los Angeles machine, maximum (\%), } \\
\text { Tread, } 500 \text { revolutions }\end{array}$} & E-218 & - & 25 & 20.7 & Complies \\
\hline \multicolumn{2}{|c|}{$\begin{array}{l}\text { Abrasion degradation in Micro-Deval equipment, } \\
\text { maximum }(\%)\end{array}$} & E-238 & - & 25 & 17.82 & Complies \\
\hline \multirow[b]{2}{*}{$\begin{array}{l}\text { Mechanical strength by } 10 \% \text { fine } \\
\text { method, Rolling layer }\end{array}$} & Dry value $(\mathrm{kN})$ & \multirow[b]{2}{*}{ E-224 } & - & - & 100 & - \\
\hline & $\begin{array}{l}\text { Wet / dry ratio } \\
(\%)\end{array}$ & & - & - & 60 & - \\
\hline \multicolumn{7}{|l|}{ DURABILITY } \\
\hline \multirow{2}{*}{$\begin{array}{l}\text { Losses in solid magnesium sulfate } \\
\text { test, maximum }(\%)\end{array}$} & $\begin{array}{l}\text { Coarse } \\
\text { aggregate }\end{array}$ & \multirow{2}{*}{ E-220 } & \multirow[t]{2}{*}{ - } & \multirow[t]{2}{*}{18} & 1.5 & Complies \\
\hline & Fine aggregate & & & & 5.6 & Complies \\
\hline \multicolumn{7}{|l|}{ CLEANING, THICK ADDED } \\
\hline \multicolumn{2}{|c|}{ Impurities in coarse aggregate, maximum (\%) } & E-237 & - & 0.5 & 0.47 & Complies \\
\hline \multicolumn{7}{|c|}{ CLEANING, COMBINED GRADATION } \\
\hline \multicolumn{2}{|c|}{ Plasticity index, maximum (\%) } & $\begin{array}{ll}\text { E-125 } & y \\
\text { E-126 }\end{array}$ & - & NP & NP & Complies \\
\hline Sand equivalent, minimum (\%) & & E-133 & 50 & - & 59 & Complies \\
\hline \multicolumn{7}{|c|}{ GEOMETRY OF THE PARTICLES, THICK AGGREGATE } \\
\hline \multicolumn{2}{|c|}{ Flat and elongated particles, 5: 1 ratio, maximum (\%) } & E-240 & - & 10 & 0.3 & Complies \\
\hline \multirow{2}{*}{ Fractured faces, minimum (\%) } & \begin{tabular}{ll|}
$\begin{array}{l}\text { One } \\
\text { (rolling) }\end{array}$ & side \\
\end{tabular} & \multirow{2}{*}{ E-227 } & 75 & - & 100 & Complies \\
\hline & $\begin{array}{ll}\begin{array}{l}\text { Two } \\
\text { (rolling) }\end{array} & \text { sides } \\
\end{array}$ & & 60 & - & 100 & Complies \\
\hline \multicolumn{7}{|c|}{ PARTICLE GEOMETRY, FINE ADDED } \\
\hline \multicolumn{2}{|c|}{$\begin{array}{l}\text { Angularity of the fine fraction, method A, minimum } \\
(\%) \text {, Rolling layer }\end{array}$} & E-239 & 45 & - & 49.5 & Complies \\
\hline \multicolumn{7}{|c|}{$\operatorname{ADHESIVITY}(\mathrm{O})$} \\
\hline \multicolumn{2}{|c|}{$\begin{array}{l}\text { Coarse aggregate: covering of aggregates with } \\
\text { asphaltic materials in the presence of boiling water }(\%)\end{array}$} & E-757 & \multicolumn{2}{|c|}{ REPORT } & 94 & - \\
\hline
\end{tabular}


Table III presents the results of the specific gravities and percentages of absorption of the aggregates.

Figure 2 and Table IV show the granulometric curves of the materials and the granulometric strip for an MDC-19 according to INVIAS [10].

\section{Mix Design}

The results of the asphalt mix design by the Marshall methodology are presented in Table V, obtaining an optimal asphalt percentage for the asphalt mix of $\mathrm{Pb}=5.0 \%$, which meets the criteria established by
INVIAS in Article 450-13 for an MDC-19 mix and an NT2 transit level.

\section{Experimental Stage}

The methods used to determine temperatures, cycles and experimental design are described below.

\section{Analysis of ambient temperatures and definition of cycles}

The climatic data recorded in the area by the IDEAM, were processed to obtain minimum, average and

Table III. Specific gravity of the aggregates for the MDC-19 Asphalt Mix

\begin{tabular}{|c|c|c|c|}
\hline MATERIAL & CHARACTERISTIC & $\begin{array}{l}\text { TEST } \\
\text { STANDARD }\end{array}$ & RESULTS \\
\hline \multirow{4}{*}{ Coarse aggregate } & Specific gravity dried in the oven, Gsb & \multirow{4}{*}{ INV. E - $223-13$} & 2.592 \\
\hline & $\begin{array}{l}\text { Specific gravity in saturated and superficially dry condition, } \\
\text { Gsb sss }\end{array}$ & & 2.645 \\
\hline & Apparent specific gravity, Gsa & & 2.738 \\
\hline & Absorption (\%) & & 2.05 \\
\hline \multirow{4}{*}{ Fine aggregate } & Specific gravity dried in the oven, Gsb & \multirow{4}{*}{ INV. E - $222-13$} & 2.516 \\
\hline & $\begin{array}{l}\text { Specific gravity in saturated and superficially dry condition, } \\
\text { Gsb sss }\end{array}$ & & 2.608 \\
\hline & Apparent specific gravity, Gsa & & 2.769 \\
\hline & Absorption $(\%)$ & & 3.62 \\
\hline Mineral filler & Bulk density $(\mathrm{g} / \mathrm{cm} 3)$ & INV.E $-225-13$ & 0.65 \\
\hline
\end{tabular}

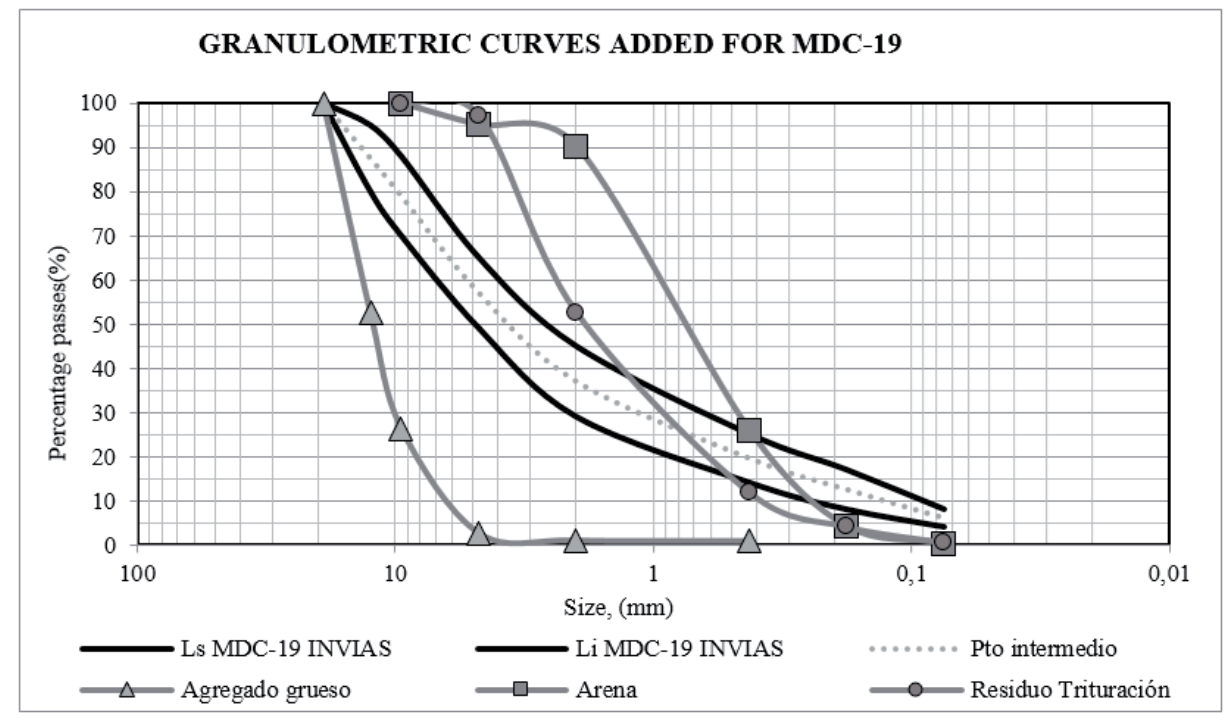

Figure 2. MDC-19 granulometric strip Article 450 INVIAS - 2013 and granulometry research aggregates Source: Author and inclusion of information from INVIAS [10].

Table IV. MDC-19 granulometric belt according to invias specific ation - 2013

\begin{tabular}{|c|c|c|c|c|}
\hline $\begin{array}{l}\text { SIEVE } \\
(\mathrm{mm})\end{array}$ & $\begin{array}{l}\text { SIEVE } \\
\text { (U.S. Standard) }\end{array}$ & $\%$ Pass Strip & $\begin{array}{l}\text { Tolerances on } \\
\text { working formula }\end{array}$ & $\begin{array}{l}\text { \% Pass Intermediate point } \\
\text { granulometric strip }\end{array}$ \\
\hline 19.0 & $3 / 4 "$ & 100 & \multirow{4}{*}{$4 \%$} & 100 \\
\hline 12.5 & $1 / 2 "$ & $80-95$ & & 87.5 \\
\hline 9.5 & $3 / 8^{\prime \prime}$ & $70-88$ & & 79.0 \\
\hline 4.75 & $\mathrm{~N}^{\circ} 4$ & $49-65$ & & 57.0 \\
\hline 2.00 & $\mathrm{~N}^{\circ} 10$ & $29-45$ & \multirow{3}{*}{$3 \%$} & 37.0 \\
\hline 0.425 & $\mathrm{~N}^{\circ} 40$ & $14-25$ & & 19.5 \\
\hline 0.180 & $N^{\circ} 80$ & $8-17$ & & 12.5 \\
\hline 0.075 & $\mathrm{~N}^{\circ} 200$ & $4-8$ & $2 \%$ & 6.0 \\
\hline
\end{tabular}


Table V. Results design of MDC-19 asphalt mixture by marshall methodology

\begin{tabular}{|c|c|c|c|}
\hline PROPERTY & $\begin{array}{l}\text { VALUE } \\
\text { OBTAINED }\end{array}$ & $\begin{array}{l}\text { INVIAS } \\
\text { SPECIFICATION - } 2013 \\
\text { MDC-19, Rolling layer, } \\
\text { NT2. } \\
\text { Article } 450-13\end{array}$ & CHECK \\
\hline$\% \mathrm{~Pb}$ & $5.0 \%$ & - & - \\
\hline$\%$ Aggregates & $95.0 \%$ & - & - \\
\hline $\mathrm{Gmb}$ & 2.393 & - & - \\
\hline Goes $(\%)$ & 3.86 & $3.0-5.0$ & Complies \\
\hline VAM (\%) & 15.5 & Minimum 15.0 & Complies \\
\hline VFA (\%) & 75.1 & $65.0-78.0$ & Complies \\
\hline Unit weight (lb / ft3) & 149.312 & - & - \\
\hline Stability $(\mathrm{N})$ & 11499 & Mínimum7500 & Complies \\
\hline Flow $(\mathrm{mm})$ & 3.34 & $2.0-4.0$ & Complies \\
\hline $\begin{array}{l}\text { Stability / Flow Ratio (kN / } \\
\text { mm) }\end{array}$ & 3.44 & $3.0-5.0$ & Complies \\
\hline
\end{tabular}

maximum temperatures according to the daily records between January 2000 and December 2016 [4]. The methodology of weighting factors (2), (3), (4), (5) and (6) was used as a guide to determine average annual weighted temperatures (TMAP), absolute minimum average weights and absolute maximum average weights [11].

$T M M\left({ }^{\circ} \mathrm{C}\right)=20.348+17.5683 \log (f p)$

$f p=10^{\left[\frac{T M M\left({ }^{\circ} \mathrm{C}\right)-20.348}{17.5683}\right]}$

$\operatorname{TMAP}_{i}\left({ }^{\circ} \mathrm{C}\right)=20.348+17.5683 \log \left(\right.$ Fprom $\left._{i}\right)$

Fprom $=\frac{\sum f p}{n}$

$T M A P \operatorname{design}\left({ }^{\circ} \mathrm{C}\right)=\frac{\sum_{i=1}^{n} T M A P_{i}}{n}$

Where: TMM: Average monthly air temperature, ${ }^{\circ} \mathrm{C}$., fp: Weighting factor., TMAP: Weighted Annual Average Air Temperature, ${ }^{\circ} \mathrm{C}$, Fprom: Average weighting factor of the year, $n$ : number of data.

Weighted average maximum and minimum temperatures were used, in order to have a representativeness of the most frequent conditions in the city, with which the effective temperatures of the minimum, maximum and average Tmix mixture are determined, through the application of the RT Letter of the SHELL methodology [12], considering a rolling layer thickness of $50 \mathrm{~mm}$. This procedure leads to the obtaining of the corresponding Tmix as presented in summary form in Table VI.

\section{Briquette Making}

For the manufacture in the laboratory of each of the 52 briquettes, the dosing of each material was carried out and for the optimal percentage of asphalt determined in the design of the mixture for each briquette of $1200 \mathrm{~g}$ in simple bachadas, the above allowed to have a better control regarding the dosing of materials and control in mixing and compacting temperatures, see Figure 3. The aggregates were heated to a temperature higher than that established for the mixture, adding the asphalt and finally combining. Next, the compaction was done with the Marshall hammer giving 75 blows on each face, allowing to cool to room temperature to unmold the next day, take dimensions and determine the initial specific gravity, Gmbi (for cycle 0) according to the standards INV-E-733-13 [9].

Table VI. Tmap weighted average annual temperatures (average, minimum and maximum) and tmix asphalt mixture temperatures obtained for tunja.

\begin{tabular}{|l|l|l|l|}
\hline $\begin{array}{c}\text { WEIGHTED ANNUAL MEDIUM } \\
\text { TEMPERATURE }\end{array}$ & \multicolumn{1}{|c|}{ ACRONYM } & $\begin{array}{c}\text { TMAP Value } \\
\left({ }^{\circ} \mathrm{C}\right)\end{array}$ & $\begin{array}{c}\text { TMIX }\left({ }^{\circ} \mathrm{C}\right) \text { FOR THICKNESS } \\
50 \mathrm{MM} \text { ASPHALT FOLDER }\end{array}$ \\
\hline $\begin{array}{l}\text { Weighted average annual } \\
\text { temperature }\end{array}$ & TMAP design & 13.3 & 20.5 \\
\hline $\begin{array}{l}\text { Average minimum weighted annual } \\
\text { average temperature }\end{array}$ & TMAPmin abs design & 5.1 & $7.7\left({ }^{*}\right)$ \\
\hline $\begin{array}{l}\text { Average maximum weighted annual } \\
\text { average temperature }\end{array}$ & TMAPmax abs design & 21.2 & $32.6\left({ }^{*}\right)$ \\
\hline
\end{tabular}

$(*)$ Working temperatures in experimental phase cycles. 


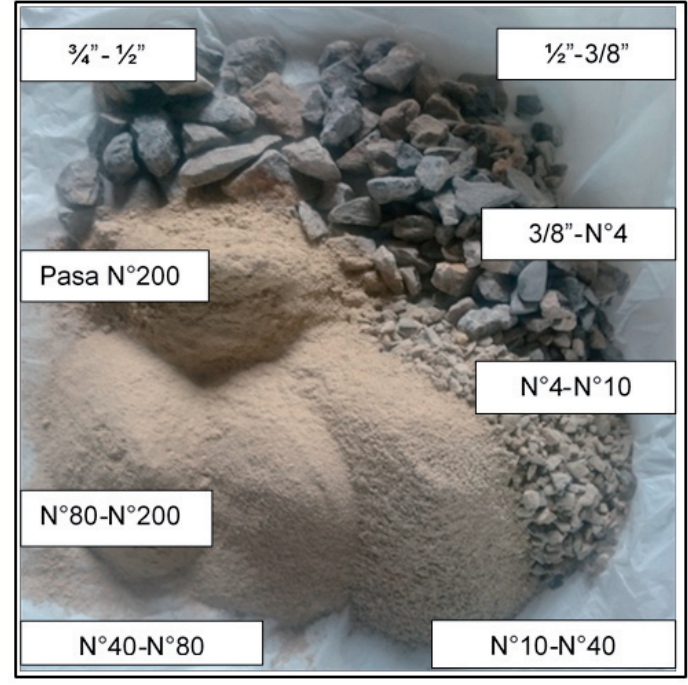

Figure 3. Aggregate dosage

All the briquettes were subjected to daily cycles, to simulate during the day at maximum temperature of the mixture in the oven $\left(32.6^{\circ} \mathrm{C}\right)$ (See Figure 4) and during the night the minimum temperature with the freezer $\left(7.7^{\circ} \mathrm{C}\right)$ (see Figure 5), each 12-hour phase.

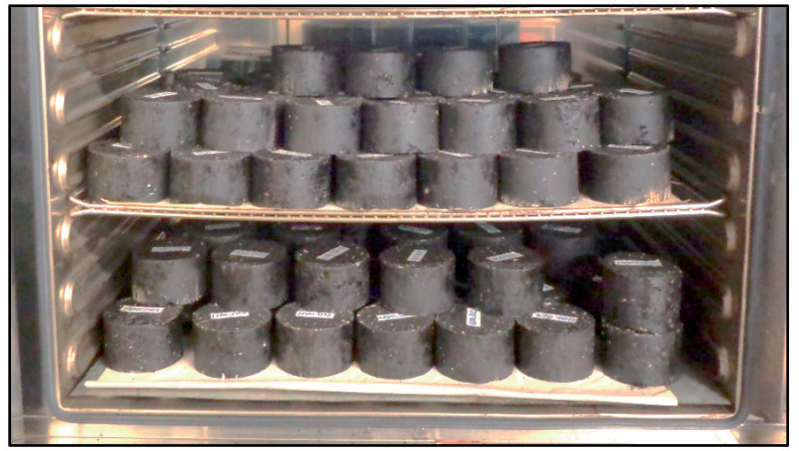

Figure 4. Experimental stage briquettes subjected to maximum oven temperature

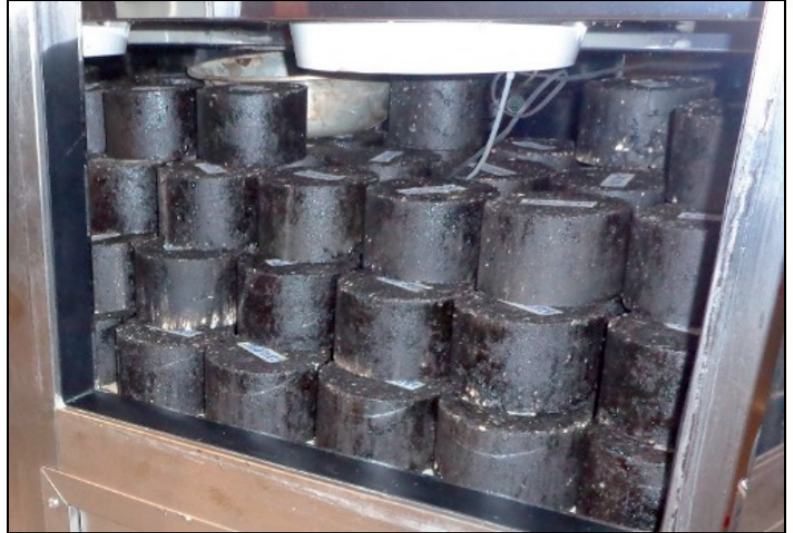

Figure 5. Experimental stage briquettes subjected to minimum freezer temperature

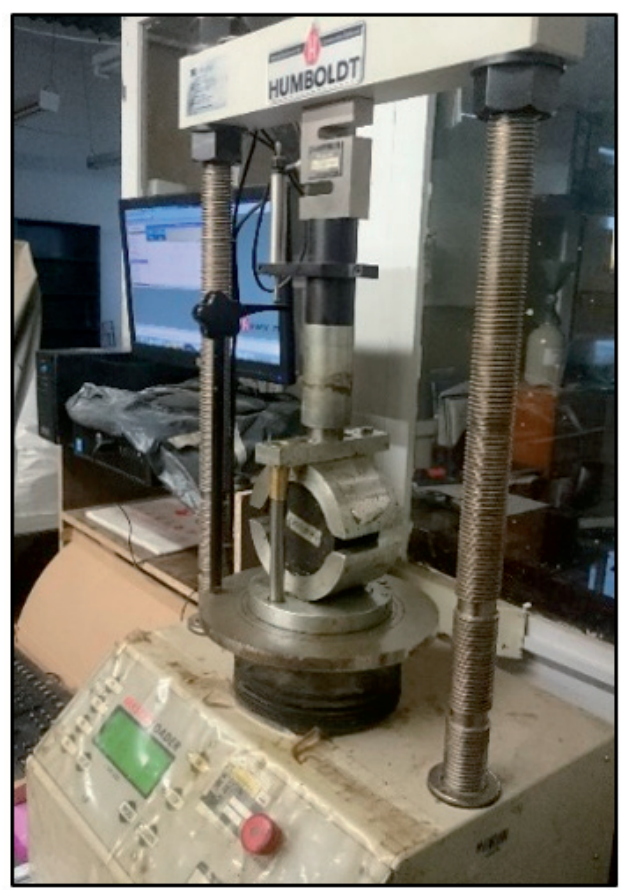

Figure 6. Equipment and test Stability and Marshall Flow

Table VII. Number of samples experimental design

\begin{tabular}{|c|c|c|c|}
\hline \multicolumn{4}{|c|}{ DURATION EXPERIMENTAL STAGE } \\
\hline $\begin{array}{c}\text { Number of daily } \\
\text { temperature } \\
\text { cycles } \\
\begin{array}{c}\text { (12h Tmax }+12 h \\
\text { Tmin) }\end{array}\end{array}$ & $\begin{array}{c}\text { Maximum } \\
\text { duration for } \\
\text { briquettes to } \\
\text { cycle }\end{array}$ & $\begin{array}{c}\text { Amount of } \\
\text { trial days }\end{array}$ & $\begin{array}{c}\text { Total trial days (includes } \\
\text { cycle 0) }\end{array}$ \\
\hline 120 cycles & $\begin{array}{c}120 \text { days }=17 \\
\text { weeks }\end{array}$ & 3 days / week & 52 days \\
\hline \multicolumn{3}{|c|}{ NUMBER OF TESTS } \\
\hline $\begin{array}{c}\text { Specific gravity bulk and density of } \\
\text { compacted asphalt mixtures } \\
\text { INV E-733-13 }\end{array}$ & $\begin{array}{c}\text { Stability and flow of hot asphalt mixtures } \\
\text { using Marshall INV E-7 equipment }\end{array}$ \\
\hline \multicolumn{3}{|c|}{ A2 (*) } & $52(*)$ \\
\hline \multicolumn{3}{|c|}{ AMOUNT OF BRIQUETS } \\
\hline 52 Marshall briquettes 1200 g MDC-19 with asphalt cement AC 80-100 \\
\hline (*) For specific test day, specific gravity, Stability and flow were \\
determined for one (1) briquette.
\end{tabular}




\section{Results and Discussion}

The MDC-19 asphalt mix briquettes manufactured in the laboratory were submitted from cycle 0 to a total of 120 daily cycles of temperature variation in the laboratory and three days per week the bulk specifi c gravity was determined in the laboratory, Stability and fl ow of the mixture, testing 1 briquette after each determined cycle and keeping the remaining group that continued under the temperature cycles. The dispersions of the data obtained refl ect that both the nature in the behavior and the conditioning with increasing temperature cycles generate variation in the parameters of this investigation.

\section{Specific gravity analysis}

The results of each of the tests carried out for the determination of the specifi c gravity bulk performed on the 52 asphalt mixture briquettes during the experimental phase were recorded.

Since the asphalt mixture was closed and the water absorption results in the study mixture in all cases of the experimental phase never exceeded $0.6 \%$, that is, it was less than $2.0 \%$ in volume, the specifi c gravity of the bulk Compacted briquettes were not paraffi $n$ zed and, therefore, were determined by the method of standard INV-733-13. [9]. The initial bulk specifi c gravities of all briquettes with the compacted mixture in the laboratory had an arithmetic mean of 2.423, with a standard deviation of 0.012 . On the other hand, the specifi c fi nal bulk gravities (Gmbf) of all the briquettes submitted to the temperature cycles and tested periodically, presented an arithmetic average of 2.428 , with a standard deviation on 0.013 .

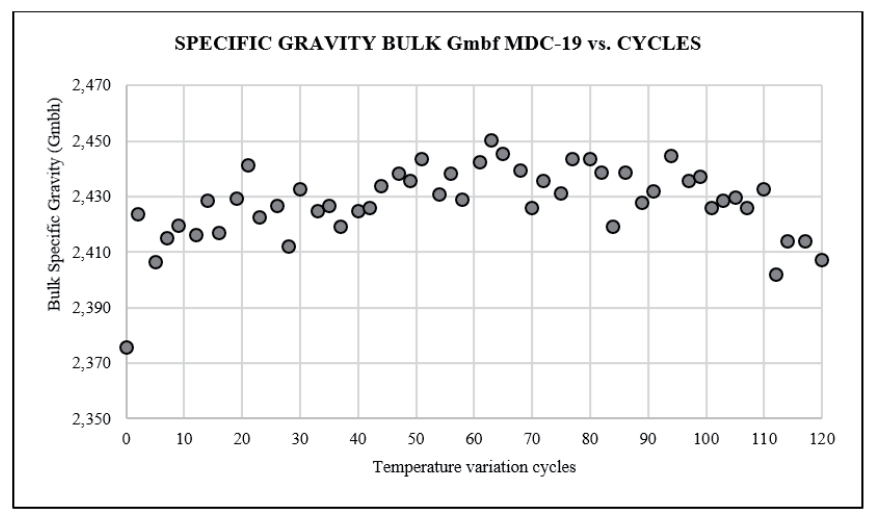

Figure 7. Specific gravity of the MDC-19 asphalt mixture before temperature cycles
Figure 7 shows the variation of specific gravities with respect to temperature cycles.

With the results of the laboratory tests, the graphs were made to visualize the trends of the specific gravity versus the number of temperature cycles, indicating that there is a progressive increase from the beginning of the experimental stage to the 72 +0.8 cycle. $\%$, from cycle 75 to cycle 84 there is a decrease until a zero variation is reached and as of cycle 97 the decrease in severity with respect to the initial one continues, obtaining variations of up to $-0.4 \%$ for the final cycles (see Figure 4 ).

It was obtained that by the end of the experimental stage (cycle 120) the mixture presented a decrease in the specific gravity with respect to the beginning of the experimental phase (Cycle 0) of -0.005 unit equivalent to a decrease of $-0.2 \%$. During the days corresponding to cycles 0 to cycle 23 , the asphalt mixture did not show water absorption; on the other hand, from cycle 26, water absorption values were obtained that vary from $0.2 \%$ to $0.6 \%$ in the last temperature cycles.

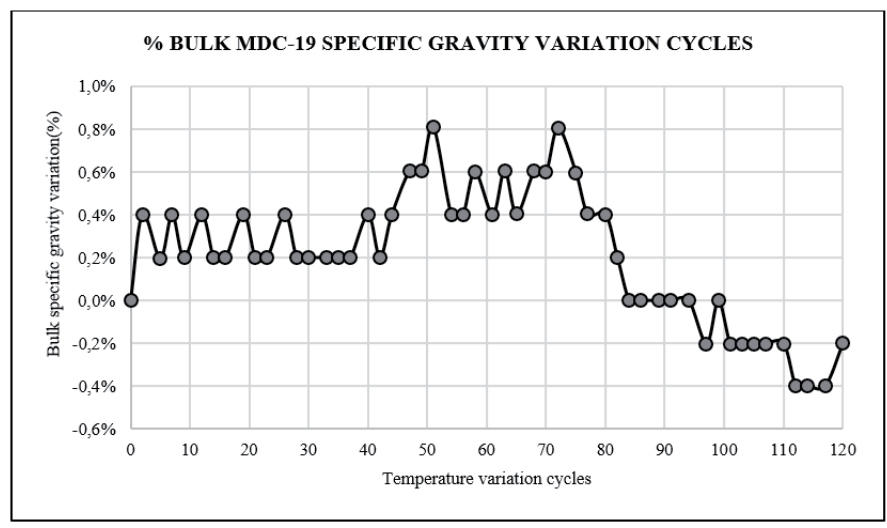

Figure 8. Percentage of variation of the specific gravity bulk $\mathrm{Gmb}$ of the asphalt mixture before the temperature cycles

There is a tendency to increase the density in the first cycles, evidenced by the increase in bulk specific gravity values from cycle 2 of temperature variation; In each of the subsequent cycles, there was a difference in oscillating $\mathrm{Gb}$ from 0.005 to 0.020 units, corresponding to $0.2 \%$ and $0.8 \%$ with respect to the initial bulk specific gravity values. From cycle 2 to cycle 84 , specific gravity values higher than those originally presented by briquettes were obtained, observing a behavior with a tendency to increase in 
the study parameter from the first temperature cycles to which the all briquettes.

Towards the middle part of the experimental stage, precisely for cycle 63 , the asphalt mix presented the highest bulk specific gravity in the entire series of tests, with a value of 2.450 . The evidenced increases in bulk specific gravity values from cycle 2 to cycle 84 could indicate an improvement in the performance of the asphalt mixture, although from that cycle until cycle 120, a decrease in the density of the mix with respect to the initial. The observed decreases in the specific gravity of the asphalt mixture may be caused by the expansion of the mixture during periods of maximum temperature and therefore, leading to increases in air voids due to temperature cycles [13], [14] and generating an increase in the percentages of water absorption for the last cycles.

\section{Stability and flow analysis}

The results of each of the tests performed for the Stability and Flow determination performed on 52 asphalt mix briquettes were recorded, with the verification of the parameters [10].

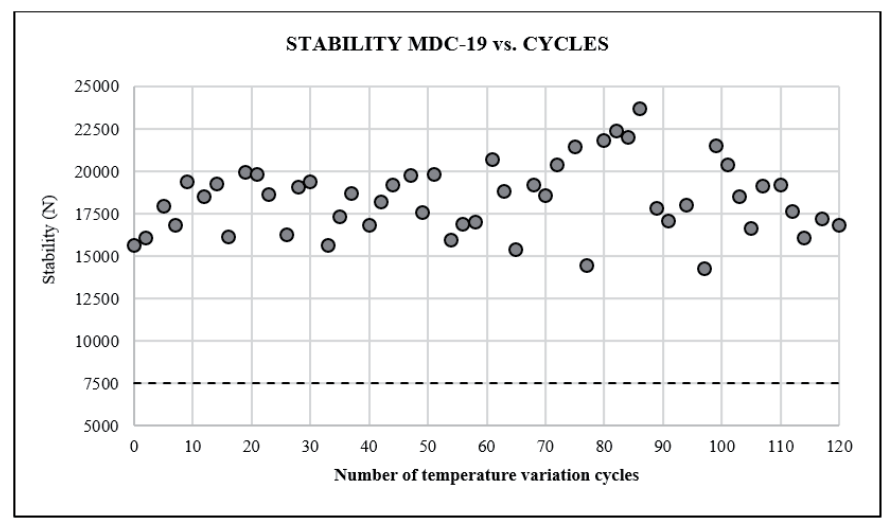

Figure 9. Variation Stability of the MDC-19 mixture with respect to thedaily cycles of ambient temperature

It was observed that the mixture maintained the values of stability, flow and Stability / Flow ratio, within the parameters of article 450 INVIAS - 2013 from cycle 0 to cycle 26 ; as of cycle 28 the mixture does not meet the flow parameters or stability / flow ratio, although for certain cycles $(40,42,44,49,65$, $89,91,94,97,103,110$ to 120$)$ the mix again meets all the parameters.

The previous trend is due to the fact that continuous

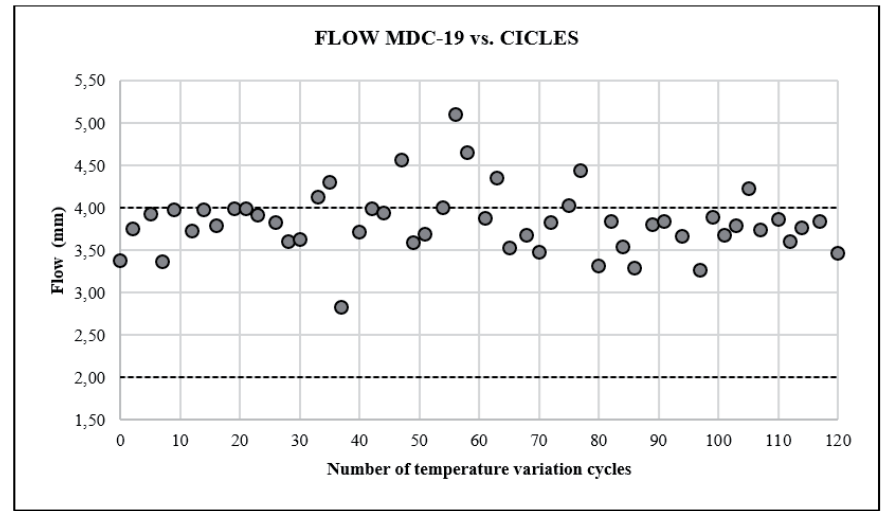

Figure 10. Variation of the MDC-19 mixture fl ow with respect to daily ambient temperature cycles

temperature changes in the asphalt mix cause the fl ow to increase by exceeding the verification parameters by up to $1 \mathrm{~mm}$, this is related to the increase in water absorption values. In the cycles in which the fl ow is increased, the stability / fl ow ratio decreases, which is justifi ed by the effect of the aging of asphalt cement by oxidation in the face of temperature changes to which the asphalt mixture is exposed [15] - [16]. Similarly, it occurs with the Stability / Flow ratio, since for some cycles the asphalt mixture has increased resistance values, but with low deformations caused by the rigidity of the mixture. See Figure 11.

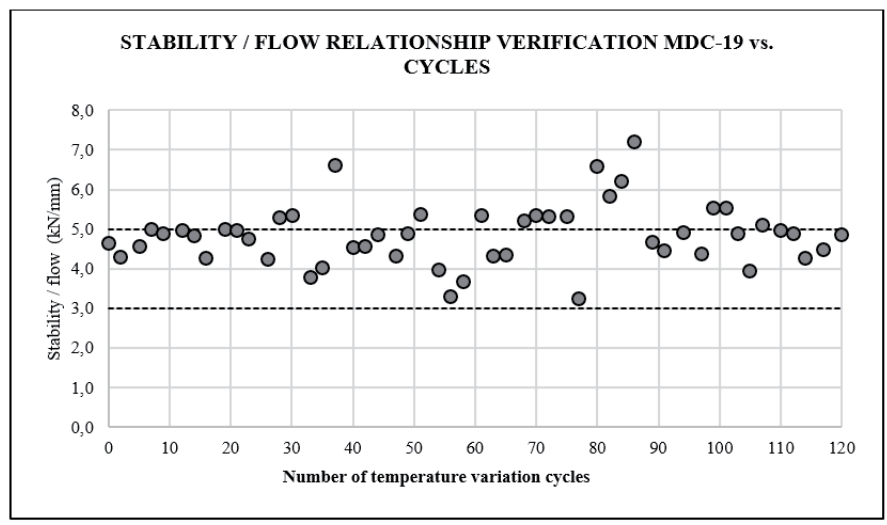

Figure 11. Verification of the Stability / Flow Ratio parameter for the MDC-19 mixture under the daily ambient temperature cycles

\section{Conclusions}

From the analysis of temperatures obtained from the registration series of the IDEAM Meteorological Station, it was possible to confi $\mathrm{rm}$ that there is a signifi cant variation in the ambient temperatures to which the pavements are subjected daily in the city of Tunja. In the registry data series, it was found that, in the period from January 2000 to December 2016, 
absolute minimum ambient temperatures of $-0.6^{\circ} \mathrm{C}$ and absolute maximum ambient temperatures of $25.4^{\circ} \mathrm{C}$ have been sporadically presented and, that the weighted minimum and maximum weighted average ambient temperatures are respectively $5.1^{\circ} \mathrm{C}$ and $21.2^{\circ} \mathrm{C}$, which are transmitted to the rolling layer of a $50 \mathrm{~mm}$ thick asphalt mixture, until an effective temperature of the mixture is obtained ( Tmix) of $7.7^{\circ} \mathrm{C}$ and $32.6^{\circ} \mathrm{C}$, in each case for the definition of daily temperature cycles.

The materials used (stone aggregates and asphalt cement CA 80-100) and the MDC-19 hot dense asphalt mixture designed and manufactured in the laboratory for this investigation, meet the requirements of INVIAS - 13 for NT2 transit level and the typical conditions of the city of Tunja.

The variations that occur daily in the ambient temperature for the city of Tunja, have an influence on the density of the MDC-19 type INVIAS asphalt mixture causing this parameter to increase as it is subjected to temperature cycles, but It reaches a point where this property shows a decrease towards the end of the stage of exposure of the samples to the cycles. The asphalt mixture presented an increase in water absorption.

From the point of view of resistance to deformation, the MDC-19 asphalt mixture did not show variations that would affect compliance with the parameter established by INVIAS during the 120 temperature cycles analyzed. However, for the briquettes subjected to temperature cycles after 28 days, a panorama was evident in which the flow criteria and / or stability and flow ratio were not met, mainly due to the stiffness of the asphalt mixture.

The evaluation of the behavior of an asphalt mixture exposed to cycles of temperature variation in the laboratory that simulate local daily conditions, allows to have a point of comparison to determine the relationship between the increase of said cycles and density, which finally allow us to deduce that the Ambient temperature variation is a factor that generates some effect on the performance of the mixture. This consideration should be taken into account when designing an asphalt mixture, since generally weighted average temperatures are taken into account and not the effect of maximum temperatures and minimum temperatures to which these materials will be subjected daily throughout of pavement life.

\section{References}

[1] G. Valdés, F. Pérez-Jiménez and A. Martínez, "Influencia de la temperatura y tipo de mezcla asfáltica en el comportamiento a fatiga de los pavimentos flexibles", Revista de la Construcción, vol. 11, pp. 87-100, 2012. doi: 10.4067/S0718-915X2012000100009.

[2] O. Reyes, J. Camacho and F. Reyes, "Influencia de la temperatura y nivel de energía de compactación en las propiedades dinámicas de una mezcla asfáltica", Revista Facultad de Ingeniería Universidad de Antioquia. pp. 126, 2006.

[3] DEAM Instituto de Hidrología, "Meteorología y Estudios Ambientales de Colombia, Subdirección de Meteorología", Cartas climatológicas de las principales ciudades, UPTC, 2016.

[4] IDEAM Instituto de Hidrología, Meteorología y Estudios Ambientales de Colombia, Subdirección de Meteorología, "Informes digitales de registros de variables climáticas de la ciudad de Tunja, Serie Años 2000 a 2016", Estación IDEAM-UPTC Tunja, Colombia, 2017.

[5] K. Nesnas and M. Nunn, "A Model for topdown Reflection Cracking in Composite Pavements", Fifth International RILEM Conference on Reflective Cracking in Pavements, (Limoges, France), pp. 409-416, 2004.

[6] N. Huamán Guerrero and C. M. Chang Albitres "La deformación permanente en las mezclas asfálticas y el consecuente deterioro de los pavimentos asfálticos en el Perú", Perfiles 
de ingeniería, vol. 2, no. 11, pp. 23-31, 2016. ISSN 2519-5719. http:// revistas.urp.edu.pe/index.php/Perfiles Ingenieria/article/view/402

[7] W. Si et al., "Impact of Freeze-Thaw Cycles on Compressive Characteristics of Asphalt Mixture in Cold Regions", Journal of Wuhan University of Technology-Mater, vol. 30, pp. 703-709, 2015. doi: 10.1007/ s11595-015-1215-5.

[8] M. Kestler, R. Berg and S. Bigl, "Statistical Significance of Freeze-Thaw Related Factors on Cumulative Damage to Flexible Pavements", Transportation Research Record Journal of the Transportation Research Board, vol. 2232, no. 1, pp. 55-67, 2011. doi: 10.3141/2232-06.

[9] Instituto Nacional de Vías, "Manual de normas de ensayo de materiales para carreteras", Bogotá D.C., Colombia. INVIAS, 2013.

[10] Instituto Nacional de Vías, "Especificaciones generales de construcción de carreteras", Bogotá D.C. Colombia. INVIAS, 2013.

[11] C. H. Higuera, "Nociones sobre métodos de diseño de estructuras de pavimentos para carreteras. Volumen I y II. Tunja, Colombia", Universidad Pedagógica y Tecnológica de Colombia, pp. 8-43, 2011.

[12] Shell International Petroleum Company Limited, "Shell pavement design manual -Asphalt pavements and overlays for road traffic", Londres, Inglaterra. 1978.

[13] P. Pan, S. Wu, X. Hu, G. Liu and B. Li, "Effect of Material Composition and Environmental Condition on Thermal Characteristics of Conductive Asphalt Concrete", Materials, vol. 10, pp. 1-17, 2017. doi:10.3390/ma10030218.

[14] E. Özgan and S. Serin. "Investigation of certain engineering characteristics of asphalt concrete exposed to freeze-thaw cycles", Cold Region Science and Technology, vol. 85, pp. 131-136, 2013. doi: 10.1016/j.coldregions.2012.09.003.
[15] H. Rondón and F. Reyes, "Influence of the Bogotá environmental conditions on the mechanical behavior of an asphalt mixture", Revista ingeniería de construcción, vol. 24, pp. 195-207, 2009. doi: 10.4067/ S0718-50732009000200006.

[16] H. Rondón and F. Reyes, "Evaluation of mechanical parameters of an asphalt mixture under the environmental conditions of Bogotá D.C.", Revista Ingeniería de construcción, vol. 27, pp. 57-74, 2012. doi: 10.4067/ S0718-50732012000100004. 